\title{
Transforming knowledge by editing texts: the Auctores Britannici Medii Aevi and medieval British university philosophy
}

\begin{abstract}
John Marenbon
Abstract: Editing texts is an activity fundamental to research in the history of philosophy, but individual editions, however important, rarely transform knowledge. It is argued here, however, that, taken as a whole, the British Academy's Auctores Britannici Medii Aevi series does have this transformative effect. The project is reaching a new understanding of an important, but often neglected, area of the history of philosophy. After a brief survey of the British philosophers and theologians of the 13th and 14th century, the character of the series is described, and it is shown that it has a well-defined focus, and brings valuable but neglected philosophical material to light and explores distinctive themes. It is also argued that there is another side to this transformation, through methodological innovation in editing, as illustrated in the series.
\end{abstract}

Keywords: Oxford, Cambridge, universities, British, editing, Aristotle, logic.

Note on the author: John Marenbon is Senior Research Fellow, Trinity College, Cambridge, and Honorary Professor of Medieval Philosophy, University of Cambridge. He was elected a Fellow of the British Academy in 2009. jm258@cam.ac.uk

(C) The author(s) 2021. This is an open access article licensed under a Creative Commons Attribution-NonCommercial-NoDerivs 4.0 Unported License 
Editing texts from the distant past seems, more than almost any other type of work done in the humanities, to belong to the ordinary science of these disciplines, and to it alone. Its results are always merely incremental, and, so it is thought, the need to cultivate old-fashioned techniques, based on palaeographical and philological skill, offers no opportunity for innovation in method.

Yet maybe both of these characterisations of text editing, which can make ambitious young scholars reluctant to spend time on it, reflect not the truth, but a common misperception, caused by the tendency to see each edition in isolation, or as part of a limited project, such as publishing the complete works of a given author.

An individual edition will rarely - in itself, rather than as a result of the use made of it-transform the way in which a whole area is conceived. But this is exactly the effect that can be achieved by a series of editions, focused on a particular area, especially a neglected one, and brought together even loosely into a project. Moreover, although there are important aspects of editing texts where the methods and ideals do not - and should not - change, this area of work, like others, can benefit from well-judged innovations.

The following pages focus on an editorial project of this type, the British Academy's series Auctores Britannici Medii Aevi (ABMA), in the form it has taken in the last two decades, with its focus on the remarkable tradition of philosophy and philosophical theology in the 13th and 14th centuries by British authors. The aim is to show how this deliberately loosely organised, but carefully managed, project is yielding a new understanding of an important, but often neglected area of the history of philosophy. The discussion begins with a brief survey of the British philosophers and theologians of the 13th and 14th centuries, before turning to ABMA itself and showing that it has a well-defined focus, which brings unjustly neglected, valuable philosophical material to light and explores distinctive themes. It will then explain how, as some of these editions show, there is, in fact, room-and sometimes need-for methodologicalinnovation in editing.

\section{0-1400: British thinkers, and philosophy and theology in England}

From the early 12 th century to about 1300, Paris was the outstanding European centre for philosophy and theology. England was the second most important centre from early in the 13th century onwards; and, arguably, in the period from about 1320 to 1350, it was pre-eminent in intellectual eminence and influence. During the whole period, however, the world of learning in Europe, with Latin as its common language, was far more international than it is today, and some of the outstanding contributions by British thinkers were made in Paris. 
The University of Paris grew, gradually and organically, from the schools there. Early in the 12th century the cathedral authorities had taken the decision to license qualified masters to open schools, and the town rapidly became a magnet for the best teachers and students of philosophy and theology (cf. Southern 1995: 198-233; Wei 2012: 8-51). Among the most famous were a number from Britain, such as the great logician Adam of the Petit-Pont (or of Balsham, in Cambridgeshire), John of Salisbury, sceptic, political theorist and pupil of Abelard, the theologian Robert of Melun, and the contemplative thinker Richard of St Victor, who was born in Scotland. The future Archbishop of Canterbury, Stephen Langton, studied and taught theology in Paris for many years in the second half of the century.

Throughout the 13th century what was, by then, the University of Paris continued to be the place where many philosophers and theologians from Britain taught and wrote. The university was organised into a faculty of Arts, where grammar, logic and other secular sciences were studied, and the higher faculties, among which was the Faculty of Theology. One of the earliest works surviving from the Paris Arts Faculty is the Treatise on the Soul, written c. 1204 by the English Master John Blund (Blund 2012). The most important Parisian theologian of the early 13th century was Alexander of Hales (in Shropshire), whose teaching, as understood and developed by his pupils, is presented in the vast Summa Fratris Alexandri. Alexander became a Franciscan c. 1136-7, and not only brought one of the chairs in theology to his new order, but also set the mould for Franciscan theology. These years were the time when Aristotle's non-logical works and their commentaries by Avicenna and Averroes first began to be known. John Blund and Alexander of Hales took their Aristotelianism from Avicenna, but two other Englishmen were among the early Parisian masters to comment on the newly available translations of Aristotle's own texts. One was Robert Kilwardby, born in Yorkshire or Lancashire in about 1215, perhaps earlier, who was most probably taught Arts in Paris in the 1230s and early 1240s (Silva 2020: 18-19); another, also teaching there in the 1230s, and who commented on a number of the texts, was Richard Rufus of Cornwall; another was Roger Bacon, probably a Paris Arts Master at the same time as Kilwardby.

Many Englishmen continued to study and teach in Paris up until the 1320s. The Franciscans had a policy of sending their best students from England to become masters in Paris, as seen in the cases of the most celebrated of all British medieval philosophers, Duns Scotus, in the 1300s, and William of Alnwick, who studied under him there. ${ }^{1}$ Three of the leading secular (not belonging to a religious order) university

${ }^{1}$ As William Courtenay (1987: 147) puts it, 'To one familiar with the intellectual history of the second half of the thirteenth century the symbiotic relationship of Paris and Oxford is accepted as fundamental.' See his discussion for further details of thinkers from Britain who studied in Paris. 
thinkers of the early 14th century, Thomas Wylton, Walter Burley and Henry of Harclay were Oxford Arts masters, went to Paris to study theology before returning to positions in England - in Henry's case Master of Theology at Oxford and Chancellor of the university.

By contrast with Paris, Oxford had started to flourish as a centre for schools only in the 1190s, yet by early in the 13th century it had become a university, smaller than that of Paris, but on the same model, with an Arts Faculty, and higher faculties of Law, Medicine (only later) and Theology. The outstanding figure associated with Oxford in the early and mid-13th century was Robert Grosseteste (c. 1170-1253), though his exact relationship to the university, where he exercised the functions of chancellor (perhaps in the 1220s, perhaps earlier) and lectured probably on both the arts and theology, remain unclear; as does whether he studied theology in Oxford. ${ }^{2}$ Grosseteste was both a pioneer in the understanding of the newly available Aristotle, and a figure strikingly different from many of his contemporaries in his methods and ways of thinking.

Grosseteste did not have direct followers, although he clearly influenced Roger Bacon. But from the 1320s onwards, English philosophy and theology began to take their own course, separate from Paris, and it became unusual for the best British scholars to go there to complete their education, some years before the beginning of the Hundred Years War in 1337 made such travel difficult (Courtenay 1987: 151-7). ${ }^{3}$ William of Ockham, Walter Chatton, Adam Wodeham, Robert Holcot, Thomas Bradwardine (all working between $c .1317$ and c. 1358), Richard Brinkley, John Wyclif and Ralph Strode (all working after c. 1350) were educated at Oxford and taught in England, and they, and other English colleagues, were among the most innovative and sophisticated thinkers anywhere in Europe in the 14th century. Cambridge University, too, though very much in Oxford's shadow, had its share of eminent philosophers and theologians in the 13th and 14th centuries. ${ }^{4}$

\section{The Auctores Britannici Medii Aevi series}

The ABMA series began in 1969, without any especial aim to concentrate on university philosophy and theology. The first volume was, indeed, centred on a philosopher, but one who lived before the age of the universities - perhaps the greatest of all British/

\footnotetext{
${ }^{2}$ The controversy about Grosseteste's biography is summarised in Lewis (2019).

${ }^{3}$ 'English' rather than 'Oxford', because, although it was a smaller and lesser university than Oxford, Cambridge, which shared with it and Paris the distinction of having Law, Theology and Medicine Faculties as well as the Faculty of Arts, should not be forgotten: see Marenbon (2020).

${ }^{4}$ See Marenbon $(2020,12-23)$.
} 
honorary British philosophers, Anselm of Aosta, Bec and Canterbury; and the works edited were in the main the testimonia to his spiritual and moral didactic teaching (Anselm 1969). Nonetheless, in the period up to 2007, five of the sixteen volumes published were editions of works by Kilwardby and Grosseteste, and three more were of works by university philosophers. ${ }^{5}$ In 2008 , it was decided to focus the series on 'British' university philosophy and theology in the 13th and 14th centuries, and the pace of publication was greatly increased, so that over half of the volumes in this more than fifty-year-old series have appeared in this final period of hardly more than a decade. Many of the writers mentioned in the last section have featured: texts edited include Kilwardby's vast commentary on the Prior Analytics (Kilwardby 2015), Aristotelian commentaries by Richard Rufus (Richard Rufus 2003, 2011, 2018), ${ }^{6}$ the first part of a complete edition of Stephen Langton's theological quaestiones (Langton 2014), one of Grossteste's most philosophically rigorous texts, about free will (Grosseteste 2017), a philosophical compendium by Roger Bacon (Bacon 2018), Henry of Harclay's most important theological work (Henry of Harclay 2008), Thomas Wylton's defence of his own interpretation of Averroes's view of the human intellect (Wylton 2010), parts of the political Dialogus by William of Ockham (William of Ockham 2011, 2019), and a treatise by John Wyclif (Wyclif 2018). Editions of further texts by Wyclif, and other writers of the later 14th century, such as Strode and Brinkley are now planned. ${ }^{7}$ Other volumes edit works by authors too little known to be included in the survey above, but, it will be contended, of great intellectual importance. ${ }^{8}$

\section{Three objections}

The sceptical reader, having read patiently so far, might now be tempted to interrupt with the following objections:

\footnotetext{
${ }^{5} \mathrm{~A}$ complete list of the volumes edited in ABMA is available at https://www.thebritishacademy.ac.uk/ publishing/specialist-scholarly-publications/auctores-britannici-medii-aevi/

${ }^{6}$ Rufus's commentary on the Metaphysics is now also nearly ready for publication.

${ }^{7}$ Another text by Wyclif, De ideis, edited by the late Ivan Mueller, will soon be published, and we are hoping to publish further editions of Wyclif left by Mueller. Editions of three important mid/later 14th-century logical works (the Summa logicae of John Dumbleton, that by Richard Brinkley, and the Obligationes of Ralph Strode (probably Chaucer's friend Strode 'philosophical Strode')) are promised and are at different stages of preparation.

${ }^{8}$ They are the commentaries on the Physics by Geoffrey of Aspall (Geoffrey of Aspall 2017), Thomas Wylton on intellectual soul (Wylton 2010), and Richard Sophista's Abstractiones (Master Richard Sophista 2016). Two of these are discussed below.
} 
No doubt the ABMA series is flourishing, and it serves a useful purpose for specialists. But the initial claim that it transforms our knowledge, in the way that an outstanding monograph or a genuine research project might do, has not been established.

First, despite what has been said, the series lacks a precise focus: it uses the anachronistic label 'British' to pick out its authors and, though it now concentrates on the universities, mixes material coming from Britain with that written by British authors abroad.

Second, what is the evidence that the field it covers is unjustly neglected? Writers such as Scotus and Ockham are already well known, and many of the philosophical and theological texts of the time are of purely antiquarian interest and can happily be ignored by the historian of philosophy.

Third, in your sketch of British philosophy in the 13th and 14th centuries you give hardly more than a list of names. The series, even after the decision to sharpen its focus, seems to consist of texts of all sorts: logic, philosophy and theology. A dip into the volumes themselves shows a heterogeneous collection of topics, from the semantics of ambiguity to the relations between Pope and Emperor, from the mechanics of perception to recondite doctrine about the Persons of the Trinity and the Beatific Vision. There seem to be no characteristics that tie the texts together into a definite field of study.

All these objections, however, can be answered.

\section{Britain and France}

With regard to the first objection, Britannici is indeed an anachronism, based on the idea that the British Academy should cover British authors (and not merely, for instance, English ones). It is a useful anachronism, however, since it includes figures such as Duns Scotus, educated at Oxford but born on the Scottish side of the border, and the influential early-14th-century theologian and Bishop of Armagh, Richard Fitzralph, who was born at Dundalk in Ireland and became a doctor of theology in Oxford. ${ }^{9}$

The more substantive objection seems to be that, instead of focusing on the philosophy being done at Oxford, the series also includes works written by British authors elsewhere, usually Paris. Yet, in fact, the two categories are so interfused that they cannot be separated. Studying and teaching at Paris was usually a period, perhaps

${ }^{9}$ For a brief introduction to Fitzralph's work, see Dunne (2019). It is hoped that Professor Dunne will be able in the future to edit a selection from Fitzralph's Lectura on the Sentences for ABMA. 
a long one, in the lives of the British thinkers, who had often studied at a university in England before they crossed the Channel, and who in most cases continued to teach or write on their return. For example, John Blund returned to Oxford to teach Aristotle there, then studied theology in Paris and probably taught it, too, at Oxford. After his period teaching Arts in Paris, Kilwardby returned to England, became a Dominican, studied and taught theology at Oxford, before finishing his life as Archbishop of Canterbury. Stephen Langton too had a long teaching career in Paris and ended by being Archbishop of Canterbury, though he seems not to have been a teacher in England. Richard Rufus was another British arts master (from Cornwall) who then returned to study and teach theology at Oxford: like Kilwardby, he became a friar, though he chose the Franciscan order (and did not become an archbishop!). For later-13th- and early-14th-century English scholars, such as Henry Harclay, William of Alnwick and Walter Burley, study in Paris was even more obviously merely a break in an England-based career.

\section{The neglect of medieval British philosophers}

In answer to the second objection, it is true that the Oxford thinkers Duns Scotus and William of Ockham are anything but neglected, even with regard to editions. Their works were published already in the early days of printing and now, thanks to their Franciscan successors, there is a fine scholarly edition of Ockham's philosophical and theological works and a monumental edition of Scotus in progress. For this reason, ABMA has not been publishing their work, with one important exception. In the second half of his career, having been summoned to the papal court at Avignon, Ockham fled to join the Emperor, Ludwig of Bavaria, and devoted himself to political writing, using his logical and philosophical training to support the imperial cause. These writings were not edited with his philosophical and theological works. Over twenty years ago ABMA included the fourth volume of his collected political works (William of Ockham 1997), and the series is now publishing, section by section, the most ambitious and extended of them, the Dialogus, available up until now only in unreliable, early printed versions.

With regard to the period before Scotus, however, the great English philosophers and theologians have been badly served by modern editions, compared to purely continental figures, such as Albert the Great, Aquinas, Bonaventure and Henry of Ghent. The importance of Grosseteste, Bacon and Wyclif was recognised early on, and as a result there were 19th- and early-20th-century collective editions of some of their work, which need to be completed and, in many cases, replaced. Kilwardby, however, was almost totally neglected, and one of the factors that has enabled the 
recent surge in work on him were the ABMA editions of some of his treatises in the 1970s and 1980s. ${ }^{10}$ Henry of Harclay, a significant early-14th-century thinker, could only be read in manuscript until the recent edition of his major work (Henry of Harclay 2008). Although most of the major writings of Wodeham and Chatton have now been edited, the position for most other 14th-century British philosophers and theologians up to Wyclif is dire, with their work still available only in manuscript or, sometimes, early printed editions. There are not yet modern editions of any but isolated questions by Robert Holcot, and one of the most important works of 14th-century English theology, Thomas Bradwardine's De causa Dei, must still be read in a 17th-century edition. There would be plenty of work for ABMA to do, even if it kept to the recognised major writers.

But what of those who are not yet recognised? There are certainly many 13th- and 14th-century British university writers who deserve to be left in obscurity, but there are a large number - how many we do not yet know - whose works, once they have been edited and analysed, contain brilliant and surprising ideas and arguments. One striking example is Robert Greystones. Greystones was, until very recently, a shadowy figure, an English Benedictine who studied and taught at Oxford between about 1306 and 1326. His surviving works, all in a single Westminster Abbey manuscript, had never been printed and very rarely mentioned (see Greystones 2017: xi-xxi). A group of scholars began to investigate him because of his close relations with the better-known Henry of Harclay and because, unlike most medieval writers, he gives the names of the contemporaries whose arguments he discusses. Their work led to an edition of Greystones's various discussions of the freedom of the will (Greystones 2017). But the team found more in Greystones than they expected.

Although recent studies have shown that medieval philosophers thought about a variety of sceptical problems (Perler 2006, Lagerlund 2010), it is generally accepted that none of them doubted that humans can have knowledge, in the radical manner of Descartes at the beginning of the Meditations. Descartes did indeed adapt a characteristically medieval apparatus to set up his extreme scepticism: God's absolute power to do whatever does not involve a contradiction. But, historians have agreed, no medieval thinker had used it in this way (see Greystones 2020: xxv-xxvi). As Greystone's editors have now shown, however, they were wrong (Greystones 2020: xi-xxviii). Greystones uses God's absolute power precisely to doubt and ultimately deny the possibility of human knowledge, except for a very restricted range of truths, such as those of logic, and that I exist. God can, Greystone's insists, at any time use

\footnotetext{
${ }^{10}$ Kilwardby's De Ortu Scientiarum (Kilwardby 1976), and De Tempore and De Spiritu Fantastico (Kilwardby 1987) were published in the 1970s and 1980s. For the revival of interest in Kilwardby, see Lagerlund \& Thom (2013), Thom (2019), Silva (2020).
} 
his absolute power to, for instance, make me see something that does not exist. Unlike Descartes, for Greystones scepticism is not a stage, to be surpassed, in the quest for knowledge. Descartes believed that, starting from the cogito, he could establish the existence of God and then use God's goodness to dispel the hypothesis that he is being deceived about everything where deception is possible. Greystones rejects this escape route from scepticism. One of the truths we can know, he acknowledges, is indeed that God does not deceive people, but God does not deceive if he causes a vision of a non-existent thing. Rather, it is we who deceive ourselves, by failing to bear in mind that any object we see might be a vision of a non-existent thing (Greystones 2020: 398-9; cf. xxi). The ideas of the until now obscure Greystones mean the history of scepticism needs to be rewritten.

\section{Aristotle, logic and the distinctive style of medieval British university philosophy}

The third objection is equally unfounded. The medieval British university philosophers and theologians share a style of intellectual enquiry that is marked out by an adherence to logical argumentation and analysis, close to that of contemporary analytical philosophers, and the fundamental position it gives to Aristotle. Most students at medieval universities, who did not finish even the Arts course, spent by far the greater part of their time studying logic, both through careful reading of Aristotle's Organon and discussion of the issues it raised, and by engaging in logical exercises (sophismata) within the newly invented branches of medieval logic. In the ABMA series, the first type of study is represented by Kilwardby's commentary on the Prior Analytics, and the second by Master Richard's Abstractiones. ${ }^{11}$ But logical training is evident in all the texts, and strikingly so in the theological ones - to the extent that, for Stephen Langton, even the profoundest doctrinal problems seem to be soluble by making the right logical and semantic distinctions.

Langton was writing in the late 12 th or very early 13 th century, and his focus on logical analysis is particularly evident, because his knowledge of Aristotle is limited to his logical works. In the following decades, Aristotle's non-logical writings-his physics and biology, philosophy of mind, metaphysics, ethics and politics—all became available and the curriculum of the Arts faculties was based around them (as well as logic). Even thinkers like Kilwardby, who rejected many Aristotelian principles, could

\footnotetext{
${ }^{11}$ In the next few years, ABMA will also be publishing editions of a number of works by important 14th-century Oxford logicians: Richard Brinkley's Summa logicae, John Dumbleton's Summa Logicae and Ralph Strode's Obligationes.
} 
not but work within a mainly Aristotelian conceptual framework. The ABMA series is particularly rich in editions that show how Aristotle's non-logical works began to be studied. Richard Rufus was among the earliest Arts masters in Paris to study and lecture on these texts, and his commentaries the first, or among the first, on them. Geoffrey of Aspall, whose question-commentary on the Physics is published in the series, is coming to be recognised, as previously anonymous commentaries are attributed to him, as a very important Aristotelian in mid-13th-century Oxford. An earlier stage of Oxford Aristotelianism is represented by the literal commentary of Adam of Bockenfield on On Memory and Reminiscence, shortly to appear in ABMA. ${ }^{12}$

Logic and Aristotelianism are, of course, a shorthand for the style of philosophy followed in the medieval universities generally, and not just in England or by British authors. But there may be something distinctive about the British tradition. The remarkable English thought of the period from 1320 to 1400, which influenced the rest of Europe, was based especially on a certain approach to logic, from which psychological and metaphysical considerations were eliminated-one that is close to the manner of 12 th-century logicians, and also bears some remarkable affinities with the approach of analytic philosophers in the 20th and 21 st centuries, so that texts written in this tradition may be of special interest to them.

It has been argued that this approach continued in England in the 13th century, when a different style of logic (linked to the idea of modes of being, being thought and being signified) became dominant in Paris, one of the pieces of evidence for it being none other than the Abstractiones of Richard Sophista (Ebbesen 1985). Although this story now seems too simple, the hypothesis of an Oxford-Paris split has not been rejected, but merely qualified..$^{13}$ English-style logic seems to have lingered in some places in Paris late into the 13th century. But, as De Libera points out, this is hardly surprising given the number of English Arts masters teaching there. What is clear is that, without editions of many more texts by 13 th- and 14th-century British university thinkers - both those written in England, and those from Paris - it will not be possible to disentangle the various strands of influence and see whether there was a distinct British tradition.

\footnotetext{
${ }^{12}$ The edition is the work of Julie Brumberg-Chaumont (who has contributed a wide-ranging study of the early tradition of commentary in this text) and Dominic Poirel.

${ }^{13}$ See De Libera (1982), and his most recent comments in De Libera (2018).
} 


\section{Methodological innovations in editing}

The sections above have illustrated how understanding of an area can be transformed when new texts are made available. To the outsider it may seem that the process of editing such material requires great skill, but leaves no room for editors to develop new methods. The example of many of the volumes in the ABMA series shows how, on the contrary, the editors of complex medieval texts today have special duties and opportunities, and face fresh challenges, both of which require innovation.

Traditionally, editors of specialised medieval Latin texts have addressed themselves uncompromisingly to a readership as learned as themselves. They presented the best text they could establish - the one, in their view, nearest to the author's intentions - with a textual apparatus to show how they reached it and an introduction, discussing the manuscripts and their relations, and thereby justifying their editorial policy. There was the polite assumption that they and their readers could, of course, understand the text-though in some cases it is not hard to show that it was unwarranted, even so far as the editors themselves were concerned. Today, however, many readers demand, and many editors feel it their duty to provide, whatever help is needed to make the texts more accessible to a wider, though usually still specialised, public. Those responsible for the two multi-volume sub-projects within ABMA, the edition of Ockham's vast political Dialogus and that of the Aristotle commentaries of Richard Rufus, have risen to this challenge by having open-access websites, where their work in progress is made available, along with other material to help readers to understand the authors and the problems. ${ }^{14}$ Many of the printed editions now contain parallel translations, which cater for the new wider audience of medievalists and historians of philosophy who cannot read Latin easily, but also cannot but tackle on every line the interpretative problems posed by the material. Almost all the texts of the sort published in ABMA are not easy to understand: unfamiliarity with their genre, vocabulary and assumptions can bar them to philosophical readers from a different background, whilst sorting out the arguments and their interconnections is a challenge for specialists too. A number of editors have helped with both of sorts of problems by providing in their Introductions lengthy analytical discussions of the text edited. $^{15}$

Sometimes the material itself requires an editor to abandon the traditional methods and devise procedures more suitable for it. Take the Quaestiones Theologiae of Stephen Langton. They are not a unified text which could be established by collating

\footnotetext{
${ }^{14}$ For the Dialogus edition, see http://publications.thebritishacademy.ac.uk/pubs/dialogus/ockdial.html. For Richard Rufus, see http://rrp.stanford.edu/index.shtml

${ }^{15}$ See especially Grosseteste (2017), Wyclif (2018), Greystones (2020).
} 
manuscripts and making a stemma, in the traditional manner. Rather, it seems that they 'must have originated in varying sets of material elements ... gathered together without being bound in a fixed order', as the Introduction to the edition explains. These elements were brought together to form two families of texts - but this is a result the editors could reach only by meticulous comparison of the seven surviving collections.

\section{Conclusion}

What has been presented here is an argument of general application, but it can be effective only when developed, as here, in a particular case (medieval British university philosophy and the ABMA series). In many fields, not just medieval studies, editing texts has a central role. Scholars in these fields recognise the importance of this work, but to many on the outside it can seem laborious but limited in its intellectual resonance. The argument given here is designed to challenge that common perception. Taken, not individually, but as part of projects - as in the case of ABMA - editions of texts can be seen to have the power, normally attributed only to outstanding monographs and articles, to transform our understanding of an area, and editing calls not just for training and diligence, but often makes room for, or requires, real innovation.

\section{References}

Anselm of Canterbury (1969), Memorials of St. Anselm, ed. R.W. Southern \& F.S. Schmitt (Auctores Britannici Medii Aevi, 1; British Academy/Oxford University Press).

Bacon, Roger (2018), Compendium of the Study of Philosophy, ed. and trans. T.S. Maloney (Auctores Britannici Medii Aevi, 32; British Academy/Oxford University Press).

Blund, John (2012), Treatise on the Soul, ed. D.A. Callus \& R.W. Hunt, trans. with introduction by M.W. Dunne (Auctores Britannici Medii Aevi, 2, new edn; British Academy/Oxford University Press).

Courtenay, W.J. (1987) Schools and Scholars in Fourteenth-century England (Princeton, NJ Princeton University Press).

De Libera, A. (1982), 'The Oxford and Paris Traditions in Logic', in N. Kretzmann, J. Pinborg \& A. Kenny (eds) The Cambridge History of Later Medieval Philosophy (Cambridge, Cambridge University Press), 174-87. https://doi.org/10.1017/CHOL9780521226059.010

De Libera, A. (2018), 'Le split Oxford/Paris', lecture viewable at:

https://www.college-de-france.fr/site/en-alain-de-libera/symposium-2018-05-14-09h45.htm

Dunne, M.W. (2019), 'Richard FitzRalph', in E. Zalta (ed.) The Stanford Encyclopedia of Philosophy, Summer 2019 edn. https://plato.stanford.edu/archives/sum2019/entries/fitzralph/ 
Ebbesen, S. (1985), 'OXYNAT: A Theory about British Logic', in O. Lewry (ed.) The Rise of British Logic: Acts of the Sixth European Symposium on Medieval logic and Semantics (Papers in Mediaeval Studies, 7; Toronto, Pontifical Institute of Mediaeval Studies), 1-17.

Geoffrey of Aspall (2017), Questions on Aristotle's Physics, ed. S. Donati \& C. Trifogli, trans E.J. Ashworth \& C. Trifogli, 2 vols (Auctores Britannici Medii Aevi, 22-7; British Academy/Oxford University Press).

Greystones, Robert (2017), Robert Greystones on the Freedom of the Will: Selections from his Commentary on the Sentences, ed. M. Henninger, R. Andrews \& J. Ottman (Auctores Britannici Medii Aevi, 28; British Academy/Oxford University Press).

Greystones, Robert (2020), Robert Greystones on Certainty and Scepticism: Selections from his works, ed. R. Andrews, J. Ottman \& M. Henninger (Auctores Britannici Medii Aevi, 34; British Academy/ Oxford University Press).

Grosseteste, Robert (2017), The Two Recensions of 'On Free Decision', ed. N. Lewis (Auctores Britannici Medii Aevi, 29; British Academy/Oxford University Press).

Henry of Harclay (2008), Ordinary Questions, ed. M. Henninger, trans. R. Edwards \& M. Henninger, 2 vols (Auctores Britannici Medii Aevi, 17-18; British Academy/Oxford University Press).

Kilwardby, Robert O.P. (1976), De Ortu Scientiarum, ed. Albert G Judy (Auctores Britannici Medii Aevi, IV; British Academy/Oxford University Press).

Kilwardby O.P., Robert (1987), On Time and Imagination (De Tempore, De Spiritu Fantastico), ed. P.O. Lewry (Auctores Britannici Medii Aevi, IX; British Academy/Oxford University Press).

Kilwardby, Robert (2015), Notule libri Priorum, ed. and trans. P. Thom \& J. Scott, 2 vols (Auctores Britannici Medii Aevi, 23-24; British Academy/Oxford University Press).

Lagerlund, H. (ed.) (2010), Rethinking the History of Skepticism: The Missing Medieval Background (Leiden, Brill). https://doi.org/10.1163/ej.9789004170612.i-238

Lagerlund, H. \& Thom, P. (eds) (2013), A Companion to the Philosophy of Robert Kilwardby (Brill's Companions to the Christian Tradition, 37; Leiden and Boston, MA, Brill).

Langton, Stephen (2014), Quaestiones Theologiae, Liber I, ed. R. Quinto \& M. Bieniak (Auctores Britannici Medii Aevi, 22; British Academy/Oxford University Press).

Lewis, N. (2019), 'Robert Grosseteste', in E. Zalta (ed.) The Stanford Encyclopedia of Philosophy, Summer 2019 edn. https://plato.stanford.edu/archives/sum2019/entries/grosseteste/

Marenbon, J. (2020), 'Introduction: New Perspectives on the Early Fourteenth Century Universities, and Cambridge as a Centre of Intellectual Life', in J. Marenbon (ed.) King's Hall., Cambridge and Fourteenth-century Universities (Education and Society in the Middle Ages and Renaissance, 56; Leiden and Boston, MA, Brill), 1-26. https://doi.org/10.1163/9789004435056

Perler, D. (2006), Zweifel und Gewissheit. Sketische Debattem im Mittelalter (Frankfurt, Klostermann).

Richard Rufus of Cornwall (2003), In Physicam Aristotelis, ed. R. Wood (Auctores Britannici Medii Aevi, 16; British Academy/Oxford University Press).

Richard Rufus of Cornwall (2011), In Aristotelis De generatione et corruptione, ed. N. Lewis \& R. Wood, with J. Ottman (Auctores Britannici Medii Aevi, 21; British Academy/Oxford University Press).

Richard Rufus of Cornwall (2018), Sententia cum quaestionibus in libros De anima Aristotelis, ed. J. Ottman, R. Wood, N. Lewis \& C. Martin (Auctores Britannici Medii Aevi, 31; British Academy/ Oxford University Press).

Master Richard Sophista (2016), Abstractiones, ed. M. Sirridge \& S. Ebbesen with E.J. Ashworth (Auctores Britannici Medii Aevi, 25; British Academy/Oxford University Press).

Silva, F. (2020), Robert Kilwardby (New York, Oxford University Press). https://doi.org/10.1093/oso/9780190674755.001.0001

Southern, R.W. (1995), Scholastic Humanism and the Unification of Europe, I: Foundations (Oxford, Blackwell). 
Thom, P. (2019), Robert Kilwardby's Science of Logic: A Thirteenth-century Intensional Logic (Investigating Medieval Philosophy, 14; Leiden, Brill). https://doi.org/10.1163/9789004408777

Wei, I.P. (2012), Intellectual Culture in Medieval Paris. Theologians and the University, c. 1100-1330 (Oxford, Oxford University Press). https://doi.org/10.1017/CBO9780511842108

William Ockham (1997) Opera Politica, IV, ed. H.S. Offler (Auctores Britannici Medii Aevi, XIV; British Academy/Oxford University Press).

William of Ockham (2011), Dialogus, Part 2; Part 3, Tract 1, ed. J. Kilcullen, J. Scott, J.Ballweg \& V. Leppin (Auctores Britannici Medii Aevi, 20; British Academy/Oxford University Press).

William of Ockham (2019), Dialogus, Part 3, Tract 2, ed. S. Heinen \& K. Ubl (Auctores Britannici Medii Aevi, 33; British Academy/Oxford University Press).

Wyclif, John (2018), De scientia Dei, ed. L. Campi (Auctores Britannici Medii Aevi, 30; British Academy/ Oxford University Press).

Wylton, Thomas (2010), On the Intellectual Soul, ed. L. Nielsen \& C. Trifogli, trans. G. Trimble (Auctores Britannici Medii Aevi, 19; British Academy/Oxford University Press).

To cite the article: John Marenbon (2021), 'Transforming knowledge by editing texts: the Auctores Britannici Medii Aevi and medieval British university philosophy', Journal of the British Academy, 9: 73-86.

DOI https://doi.org/10.5871/jba/009.073

Journal of the British Academy (ISSN 2052-7217) is published by The British Academy, 10-11 Carlton House Terrace, London, SW1Y 5AH www.thebritishacademy.ac.uk 